\title{
Bio Control Potential of Pseudomonas fluorescens against Coleus Root Rot Disease
}

\author{
S Vanitha ${ }^{1}$ and R Ramjegathesh ${ }^{2 *}$ \\ ${ }^{1}$ Department of Sericulture, Centre for Plant Protection Studies, Tamil Nadu Agricultural University, Coimbatore-641 003, Tamil Nadu, India \\ ${ }^{2}$ Department of Plant Pathology, Centre for Plant Protection Studies, Tamil Nadu Agricultural University, Coimbatore-641 003, Tamil Nadu, India
}

\begin{abstract}
Ten different strains of Pseudomonas fluorescens were isolated from coleus rhizosphere except the pf1 strain and identified by biochemical tests. These strains were screened against Macrophomina phaseolina (Tassi) Goid, the causal organism of coleus root rot. The results revealed that Pf1 strains recorded maximum inhibition of mycelial growth against control. The mechanism of Pseudomonas strains namely the iron-chelating agent (siderophore), volatiles ( $\mathrm{HCN}$ ) and antibiotic (Fluorescein and pyocyanin) production tests were studied and reacted for siderophore, antibiotic and HCN production. The talc-based formulation of Pf1 and CPF1 was prepared and the bio-efficacy was tested under greenhouse conditions. The stem cutting and soil application of the talc-based formulation of Pf1 significantly reduced the root rot incidence and increased shoot and tuber length also.
\end{abstract}

Keywords: Antibiotics; Coleus; HCN; Pseudomonas fluorescens; Root rot; Siderophore

\section{Introduction}

Coleus (Coleus forskohlii Briq.) is cultivated mainly for their medicinal values in India. In India it is cultivated on about 2,500 hectares with an annual production of 1500 tonnes, especially in parts of Rajasthan, Maharashtra, Karnataka and Tamil Nadu. In Tamil Nadu alone, it is cultivated on more than 1000 hectares across. The crop is subjected to attack by many fungal diseases, namely leaf spot (Botryodiplodia theobromae), stem blight (Phytophthora nicotianae var. Nicotianae), collar rot (Sclerotium rolfsii, and Rhizoctonia bataticola), root rot (Fusarium chlamydosporum, Rhizoctonia solani and Macrophomina phaseolina) downy mildew (Peronospora sp) $[1,2]$.

Root rot of coleus caused by M. Phaseolina is widely distributed in many countries and it is a devastating pathogen right from the establishment of the crop. Many effective fungicides have been tested against soil borne pathogens, but are not considered as long term solutions because of concerns about exposure risks, health and environmental hazards, high cost, residue persistence, the development of resistance to pesticides and the elimination of natural enemies. Biological control is a potential non-chemical means for plant disease management by reducing the harmful effects of a parasite or pathogen through the use of other living entities. The utilization of a plant's own defense mechanism is a fascinating arena of research which can be systemically activated upon exposure of plants to PGPR strains or infection by the plant pathogen. This phenomenon is called induced systemic resistance (ISR). This mechanism is facilitated by PGPR organism and activates through various defense compounds at the site of pathogen attack. Among the PGPR, fluorescent pseudomonads are the most exploited bacteria for biological control of soil-borne and foliar plant pathogens. In the past three decades, numerous strains of fluorescent pseudomonads have been isolated from the rhizosphere soil and plant roots by several workers and their biocontrol activity against soil-borne and foliar pathogens were reported [3]. Fluorescent pseudomonads are non-pathogenic rhizobacteria which suppress the soil-borne pathogens through rhizosphere colonization, antibiosis, iron chelation by siderophore production and ISR. In my knowledge, there is no report available in the control of root rot disease by Pseudomonas sps in coleus, but the use of antagonistic microorganisms such as
Pseudomonas fluorescens against Macrophomina phseolina have been reported many workers [4,5]. In the present investigation, attempts were made to test the antagonistic activity of Pseudomonas fluorescens and its mechanisms for coleus root rot management.

\section{Materials and Methods}

\section{Isolation of pathogen and Pseudomonas strains}

The root rot pathogen M. Phaseolina was isolated from coleus plants showing typical root rot symptoms and pure cultures of the pathogen were obtained by the single hyphal tip method [6]. The biocontrol agent $P$. fluorescens strain Pf1 was obtained from the culture collection section, Department of Plant Pathology, Centre for Plant Protection Studies, Tamil Nadu Agricultural University, India.

Other native coleus rhizobacterial $P$. fluorescens (CPF1 to CPF10) strains were isolated from soil samples obtained from different parts of Tamil Nadu state. One gram of rhizosphere soil adhering to root surface was collected and transferred to a $250 \mathrm{ml}$ conical flask containing $100 \mathrm{ml}$ of sterile water. After thorough shaking for 15 minutes in a shaker, different dilutions were prepared. One ml of each $10^{-5}$ and $10^{-6}$ dilution was pipetted out and poured into the sterile petridishes. Later King's medium B (KB) [7] was poured, rotated and incubated at room temperature $\left(28 \pm 2^{\circ} \mathrm{C}\right)$ for 24 hours. After 24 hours of incubation, the bacterial growth was purified by the dilution plate technique [8]. The bacterial culture was maintained in King's B broth (KB) in 30 percent $(\mathrm{v} / \mathrm{v})$ glycerol at $-80^{\circ} \mathrm{C}$.

Characterization of the different cultures of antagonistic bacteria

*Corresponding author: R Ramjegathesh, Department of Plant Pathology, Centre for Plant Protection Studies, Tamil Nadu Agricultural University, Coimbatore - 641 003, Tamil Nadu, India, Tel: +91-422-6611442; E-mail: ramjegathesh@gmail.com

Received: December 27, 2013; Accepted January 17, 2013; Published January 24, 2014

Citation: Vanitha S, Ramjegathesh R (2014) Bio Control Potential of Pseudomonas fluorescens against Coleus Root Rot Disease. J Plant Pathol Microb 5: 216. doi:10.4172/2157-7471.1000216

Copyright: $\odot 2014$ Vanitha S, et al. This is an open-access article distributed under the terms of the Creative Commons Attribution License, which permits unrestricted use, distribution, and reproduction in any medium, provided the original author and source are credited. 
was done according to the methods recommended in the laboratory guide for identification of plant pathogenic bacteria published by the American Phytopathological Society [9]. In each test, 24-48 hours-old cultures were used.

\section{Siderophores production}

Production of siderophores by $P$. fluorescens was assayed by the plate assay method as described by Schwyn and Neilands [10]. The tertiary complex chromeazurol S (CAS) served as an indicator. To prepare one litre of the blue agar, $60.5 \mathrm{mg}$ CAS was dissolved in $50 \mathrm{ml}$ water and mixed with $10 \mathrm{ml} \mathrm{Fe}^{3+}$ solution $\left(1 \mathrm{mM} \mathrm{FeCI}{ }_{2} 6 \mathrm{H}_{2} \mathrm{O}\right.$ in $10 \mathrm{mM}$ HCI and HDTMA dissolved in $40 \mathrm{ml}$ water was added by constantly stirring). A forty-eight hour-old culture of fluorescent pseudomonads was streaked onto the succinate medium (Succinic acid, $4.00 \mathrm{~g} ; \mathrm{K}_{2} \mathrm{HPO}_{4}$, $3.00 \mathrm{~g} ;\left(\mathrm{NH}_{4}\right)_{2} \mathrm{SO}_{4} .7 \mathrm{H}_{2} \mathrm{O}, 7 \mathrm{H}_{2} \mathrm{O}, 0.2 \mathrm{~g}$ : distilled water, $\left.1000 \mathrm{ml}, \mathrm{pH} 7.0\right)$ amended with the indicator and incubated for three days.

\section{Production of hydrogen cyanide}

The production of HCN was determined using a modification of the [11] procedure. Bacteria were grown on Tryptic-soy-agar (TSA) (animal peptone-5.0 g, soy peptone-5.0 g, sodium chloride-5.0 g, glycine- $4.4 \mathrm{~g}$, distilled water $1000 \mathrm{ml}$ ). Filter paper discs soaked in a picric acid solution ( $2.5 \mathrm{~g}$ of picric acid, $12.5 \mathrm{~g}$ of sodium carbonate, and $1000 \mathrm{ml}$ of distilled water) were placed in the lid of each Petriplate. Dishes were sealed with parafilm and incubated at $28^{\circ} \mathrm{C}$ for 48 hours. A change from yellow to light brown, brown or reddish brown of the discs was recorded as an indication of weak, moderate or strong production of $\mathrm{HCN}$.

\section{Detection of fluorescein and pyocyanin}

Pseudomonas agar F (Casein enzymic hydrolysate, $10 \mathrm{~g}$; Protease peptone, $10 \mathrm{~g}$; $\mathrm{K}_{2} \mathrm{HPO}_{4}, 1.5 \mathrm{~g} ; \mathrm{MgSO}_{4}, 1.5 \mathrm{~g}$; distilled water, 11) favours the formation of fluorescein whereas Pseudomonas agar P (Peptone, 20 g; $\mathrm{MgCl}_{2}, 1.4 \mathrm{~g} ; \mathrm{K}_{2} \mathrm{SO}_{4}, 10 \mathrm{~g}$; Agar, 15 g; Distilled water, 1l) stimulates pyocyanin production and reduces fluorescein formation [7].

\section{Effects of volatile metabolites}

The effect of volatile metabolites from fluorescent pseudomonads on the growth of

M. Phaseolina was studied by a paired Petri dish technique by Gagne et al. [12].

\section{Screening of antagonistic bacteria under in vitro condition}

The antifungal efficacy of Pseudomonas fluorescens strains was tested by dual culture technique [13] using PDA medium. A mycelial disc ( $9 \mathrm{~mm}$ dia) of the pathogen namely $M$. Phaseolina was placed at one end of the plate and the bacterial antagonists were streaked at the periphery of the Petri-dish just opposite to the mycelial disc of the pathogen. The plates were incubated at $28 \pm 2{ }^{\circ} \mathrm{C}$. The mycelial growth of the pathogen and inhibition zone was measured after $72 \mathrm{~h}$ of incubation.

\section{Preparation of talc-based formulation of bio control agents}

A loopful of $P$. fluorescens was inoculated into the King's B broth and incubated in a rotary shaker at $150 \mathrm{rpm}$ for 72 hours at room temperature $\left(28 \pm 2^{\circ} \mathrm{C}\right)$. After 72 hours of incubation, the broth containing $9 \times 10^{8} \mathrm{cfu} / \mathrm{ml}$ was used for the preparation of talc-based formulation. To $400 \mathrm{ml}$ of bacterial suspension, one $\mathrm{kg}$ of the talc powder (sodium ammonium silicate), calcium carbonate $15 \mathrm{~g}$ (to adjust the $\mathrm{pH}$ to neutral) and carboxy methyl cellulose (CMC) $10 \mathrm{~g}$ (as an adhesive) were mixed under sterile conditions following the method [14]. The product was shade dried to reduce the moisture content to 20 per cent and then packed in polypropylene bags and sealed. At the time of application the population of bacteria in talc formulation was checked in 2.5 to $3 \times 10^{8} \mathrm{cfu} / \mathrm{g}$.

\section{Greenhouse studies}

Coleus cuttings were treated with talc-based formulations of Pf1 and CPF1 at 0.2 per cent for each stem cutting and planted in pots. Twenty-five grams of the formulated product $(2.5 \mathrm{~kg}$ talc-based formulation mixed with $50 \mathrm{~kg}$ of farmyard manure) was given as a soil application per pot at 30 days after planting (DAP). Premixture fungicide (Carbendazim+Mancozeb) at 0.1 per cent was used as a standard check fungicide. It was applied as stem cutting treatment @ 0.2 per cent and also as a soil application@ 0.05 per cent at 30 DAP. A pure culture of $M$. Phaseolina was introduced into a sand-maize (19:1) medium and incubated for 15 days at room temperature for multiplication [15]. The potting soil (red soil: sand: cow dung manure, $1: 1: 1 \mathrm{w}: \mathrm{w}: \mathrm{w})$ was incorporated with the fungus, cuttings of coleus were surface-sterilized with $0.1 \%$ mercuric chloride for $30 \mathrm{~s}$, rinsed three times with sterile distilled water and sown at two cuttings per pot. Each treatment was maintained for three replications. All treatments were replicated three times in factorial completely randomized design (CRD).

\section{Results and Discussion}

The development of biological techniques using PGPR amended with suitable bioformulations is an emerging trend in plant protection to reduce the plant diseases caused by plant pathogens. Production of antibiotics viz., Siderophore, HCN, pyrrolnitrin, phenazine and 2,4-diacetyl phloroglucinol and lytic enzymes by $P$. fluorescens against fungal pathogens were reported by many workers $[3-5,16]$. The above facts suggest that the inhibition of root rot pathogen, M. Phaseolina by $P$. fluorescens Pf1 may be due to the production of antibiotics, siderophore mediated competition and lytic enzymes, viz., chitinase, $\beta$-1,3-glucanase which degraded the fungal cell wall and restricted the growth of fungus under in vitro conditions. In the present study, among all the $P$. fluorescens strains, the Pf1 strain had maximum inhibition of mycelial growth and produced more amount of $\mathrm{HCN}$, siderophore, pyocyanin and fluorescein in comparing to all the strains, so only the Pf1 strain was selected for this study. The biocontrol potential and production of volatile metabolites in Pf1 strain has a higher inhibitory effect followed by other Pseudomonas strains (Figure 1).

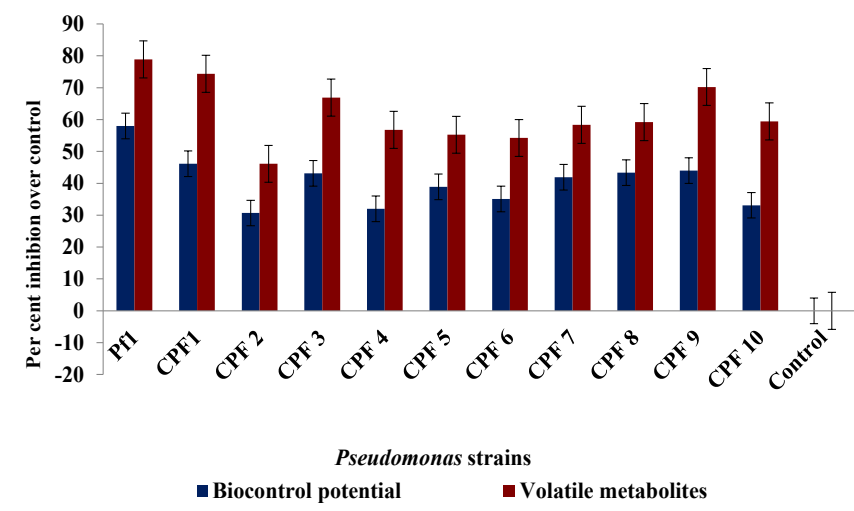

Figure 1: Bio control potential and volatile production of $P$. fluorescens against M. phaseolina under in vitro condition. 
Citation: Vanitha S, Ramjegathesh R (2014) Bio Control Potential of Pseudomonas fluorescens against Coleus Root Rot Disease. J Plant Pathol Microb 5: 216. doi:10.4172/2157-7471.1000216

P. chlororaphis strain PA23 demonstrated excellent biocontrol in the canola phyllosphere through production of the non-volatile antibiotics and volatile antibiotics nonanal, benzothiazole and 2-ethyl-1-hexanol [17]. Secondary metabolites and volatile compounds contributed to the toxicity of the bacteria, with hydrogen cyanide efficiently repelling the nematodes and both hydrogen cyanide and 2, 4-DAPG functions as nematicides. Under certain conditions, antibiotics improve the ecological fitness of these bacteria in the rhizosphere which can further influence long-term biocontrol efficacy [18].

All the bacterial isolates produced siderophore by the CAS plate assay method. But all isolates except CPF6 and CPF10 produced a yellow color in the blue colored medium. Siderophore produced by Pseudomonas spp. and other rhizobacterial organisms (Bacillus, Enterobacter) have been used in the biological control of dampingoff of cotton caused by Pythium ultimum [19]. Siderophore-mediated competition for iron by Pseudomonas sp. as well as induced resistance are primary mechanisms shown to be responsible for suppression of Fusarium wilt and this Pseudomonas culture and purified siderophore showed good antifungal activity against the plant deleterious fungi namely Aspergillus niger, A. flavus, A. oryzae, F. oxysporum and Sclerotium rolfsii [20]. Among the different Pseudomonas fluorescens tested, the intensity of $\mathrm{HCN}$ production was strong in $P$. fluorescens strains Pf1 and CPF1 followed by P. fluorescens strains CPF6 and CPF8. Normally the HCN production is directly related to inhibition of pathogen, the $P$. fluorescens strains Pf1 and CPF1 produced same amount, but Pf1 strain produced some sideophores, it's also inhibit the most pathogens. $\mathrm{HCN}$ from a $P$. fluorescens strain $\mathrm{CHA} 0$ not repressed by fusaric acid played a significant role in the disease suppression of $F$. oxysporum f.sp. radicis-lycopersici in tomato [21]. HCN production by several strains of $P$. fluorescens and their efficacy in controlling root rot of groundnut caused by M. Phaseolina [22]. Pseudomonas aeruginosa LES4, an isolate of tomato rhizosphere was found to be positive for HCN against wilt disease [23]. All the $P$. fluorescens strains produced fluorescein and pyocyanin antibiotics in the Pseudomonas agar F and p plate assay method. But all isolates except CPF3 and CPF7 were surrounded with a yellow to greenish-yellow zone on Pseudomonas agar $\mathrm{F}$ and surrounded by a blue to green zone or with a red to dark brown zone due to pyocyanin production (Table 1). A marine isolate of fluorescent Pseudomonas sp. which has the ability to produce the pyoverdine has been found to inhibit the growth of $A$. niger under in vitro conditions [20]. Similar results were [24] reported the specific production of fluorescein and pyocyanin by the Pseudomonas bacterium against Pythium.

The standardization of the mode of application of bacterial antagonists indicated that dipping of the stem cuttings together with soil application were highly effective in inhibiting root rot incidence rather than the individual application of antagonists either through stem cutting dipping or soil application. Among the bacterial antagonists tested, delivery of Pf1 as stem cutting, dipping and soil application recorded the lowest disease incidence and highest per cent

\begin{tabular}{|c|c|c|c|c|c|}
\hline S.No & PGPR strains & Fluorescein & Pyocyanin & Siderophore production & $\mathrm{HCN}$ \\
\hline 1 & $\mathrm{Pf1}$ & + & + & + & +++ \\
\hline 2 & CPF1 & + & + & + & +++ \\
\hline 3 & CPF 2 & - & - & + & + \\
\hline 4 & CPF 3 & - & - & + & - \\
\hline 5 & CPF 4 & + & + & + & + \\
\hline 6 & CPF 5 & + & + & + & + \\
\hline 7 & CPF 6 & + & + & - & ++ \\
\hline 8 & CPF 7 & - & - & + & - \\
\hline 9 & CPF 8 & + & + & + & ++ \\
\hline 10 & CPF 9 & + & + & + & + \\
\hline 11 & CPF 10 & - & - & - & + \\
\hline
\end{tabular}

+: Produced; - : Not produced (+++: Strong, ++: Medium, +: Low production)

Table 1: Antibiotics, siderophore and $\mathrm{HCN}$ production of $\mathrm{P}$. fluorescens strains.

\begin{tabular}{|c|c|c|c|c|c|c|}
\hline S. No & Treatments & $\begin{array}{l}\text { Per cent disease } \\
\text { incidence }\end{array}$ & $\begin{array}{l}\text { Per cent reduction } \\
\text { over control }\end{array}$ & $\begin{array}{l}\text { Shoot length } \\
(\mathrm{cm})\end{array}$ & $\begin{array}{l}\text { Tuber length } \\
\text { (cm) }\end{array}$ & No. of tubers/plant \\
\hline 1 & Pf1 (SCD alone) & $37.26^{d}(37.62)$ & 41.74 & $46.65^{f}$ & $26.54^{d}$ & $7.62^{\mathrm{de}}$ \\
\hline 2 & Pf1 (SA alone) & $26.53^{\mathrm{b}}(31.00)$ & 58.74 & $58.54^{b}$ & $29.96^{b}$ & $8.52^{c}$ \\
\hline 3 & Pf1 (SCD+SA) & $24.12^{\mathrm{b}}(29.42)$ & 62.50 & $63.56^{\mathrm{a}}$ & $32.86^{a}$ & $10.65^{\mathrm{a}}$ \\
\hline 4 & CPF1 (SCD alone) & $39.42^{\mathrm{e}}(38.89)$ & 21.66 & $40.26^{h}$ & $25.92^{\mathrm{cd}}$ & $6.94^{e}$ \\
\hline 5 & CPF1 (SA alone) & $33.23^{d}(35.20)$ & 23.44 & $50.93^{e}$ & $27.56^{c}$ & $7.02 \mathrm{~d}^{\mathrm{e}}$ \\
\hline 6 & CPF1 (SCD+SA)) & $32.56^{\text {cd }}(34.99)$ & 29.16 & $55.26^{c}$ & $30.92 a^{b}$ & $8.82^{c}$ \\
\hline 7 & $\begin{array}{l}\text { Pre mixture fungicide (Carbendazim } \\
+ \text { Mancozeb) (SCD alone) }\end{array}$ & $30.53^{\mathrm{c}}(33.54)$ & 52.52 & $42.26^{9}$ & $27.65^{c}$ & $7.54^{d}$ \\
\hline 8 & $\begin{array}{l}\text { Pre mixture fungicide (Carbendazim } \\
+ \text { Mancozeb) (SA alone) }\end{array}$ & $24.36^{\mathrm{b}}(29.58)$ & 62.12 & $53.65^{d}$ & $27.12^{c}$ & $8.59^{c}$ \\
\hline 9 & $\begin{array}{l}\text { Pre mixture fungicide (Carbendazim } \\
+ \text { +Mancozeb) }(S C D+S A)\end{array}$ & $18.56^{\mathrm{a}}(22.96)$ & 71.14 & $58.72^{\mathrm{b}}$ & $29.87^{b}$ & $9.56^{b}$ \\
\hline \multirow[t]{3}{*}{10} & Inoculated Control & $64.31^{f}(53.32)$ & - & $35.89^{i}$ & $20.14^{\mathrm{e}}$ & $5.54^{f}$ \\
\hline & SEd & 0.79 & & 0.84 & 0.94 & 0.28 \\
\hline & $\mathrm{CD}(0.05)$ & 1.64 & & 1.76 & 1.97 & 0.57 \\
\hline
\end{tabular}

SCD-Stem cuttings dip; SA-Soil application All Values are mean of three replications; Data followed by the same letter in a column are not significantly different from each other according to Duncan's multiple range test at $P=0.05$

Table 2: Effects of PGPR on the root rot incidence, growth characters and yield under green house condition. 
Citation: Vanitha S, Ramjegathesh R (2014) Bio Control Potential of Pseudomonas fluorescens against Coleus Root Rot Disease. J Plant Pathol Microb 5: 216. doi:10.4172/2157-7471.1000216

inhibition over the control (24.12 and $62.50 \%)$. It was followed by the application of CPF1 both as stem cutting, dipping and soil application. The chemical premixture fungicide (Carbendazim+Mancozeb) $(0.1 \%)$ recorded 71.14 per cent reduction over the control. The highest disease incidence was recorded in the inoculated control (64.31\%) (Table 2). The positive colonization ability of Pseudomonas GRC2 lies in it being the successful colonizer of the spermosphere, increasing seedling emergence, and its establishment in the rhizosphere of peanuts giving protection against M. Phaseolina resulting in enhanced yield [25]. It was further reported by Thilagavathi et al. [26] that the combined application of $P$. fluorescens (Pf1) in seed and soil applications was effective in reducing the root rot disease in green gram under greenhouse and field conditions.

The bio control agents not only controlled dry root rot, but also promoted plant growth and this gives them an advantage over the use of chemical fungicides against root rot in disease management. The studies showed that the PGPR is capable of controlling the coleus root rot. Amongst the different $P$. fluorescens strains tried, stem cutting, dipping and soil application of Pf1 was found to be suitable for the management of coleus root rot under pathogen (M. Phaseolina) inoculated soil in greenhouse condition. However, field evaluation is necessary to determine its efficacy under natural ecosystem.

\section{Acknowledgement}

I thank to Dr T. Raguchander, Professor, Dept. of Plant Pathology, TNAU for providing biocontrol agents for this work.

\section{References}

1. Kamalakannan A, Mohan L, Amutha G, Chitra K, Parthiban VK, et al. (2003) Effect of volatile and diffusible compounds of biocontrol agents against Coleus forskohlii root rot pathogens. In: Symposium on Recent Development in the Diagnosis and Management of Plant Diseases.18-20 Dec. Dharwad, Karnataka: 92.

2. Daughtrey M, Eshenaur B, Holcomb G (2006) Source: Greenhouse Product News 6: 6

3. Vivekananthan R, Ravi M, Ramanathan A, Samiyappan R (2004) Lytic enzymes induced by Pseudomonas fluorescens and other biocontrol organisms mediate defence against the anthracnose pathogen in mango. World J Micro Biotech 20: $235-244$

4. Saravanakumar D, Harish S, Loganathan M, Vivekananthan R, Rajendran L, et al. (2007) Rhizobacterial bioformulation for the effective management of Macrophomina root rot in mungbean. Archives of Phytopathology and Plan Protection 40: 323-337

5. Sendhilvel V, Buvaneswari D, Kanimozhi S, Mathiyazhagan S, Kavitha K, et al (2005) Management of cowpea root-rot caused by Macrophomina phaseolina (Tassi) Goid. using plant growth promoting rhizobacteria. J Biol Control 19: $41-46$

6. Rangaswami G (1972) Diseases of crop plants in India. Prentice Hall of India Pvt. Ltd., New Delhi, p520.

7. King EO, Ward MK, Raney DE (1954) Two simple media for the demonstration of pyocyanin and fluorescin. J Lab Clin Med 44: 301-307.

8. Waksman SA, Connick Jr WJ (1952) A tentative outline of the plate method for determining the number of microorganisms in the soil. Soil Science 14: 27-28.

9. Schaad NW (1992) Laboratory guide for identification of plant pathogenic bacteria. In: NW Schad (Ed.), The American Phytopathological Society. International Book Distributing Co., Lucknow. India.

10. Schwyn B, Neilands JB (1987) Universal chemical assay for the detection and determination of siderophores. Anal Biochem 160: 47-56.
11. Miller RL, Higgins VJ (1970) Association of cyanide with infection of birds' foot trefoil by Stemphylium rot. Phytopathology 60: 104-110.

12. Gagne SD, Quere L, Aliphat S, Lemay R, Fournier N (1991) Inhibition of plant pathogenic fungi by volatile compounds produced by some PGPR isolates (Abstr.). Can J Plant Pathol 13: 277.

13. Dennis C, Webster J (1971) Antagonistic properties of species groups of Trichoderma L. Production of non-volatile antibiotics. Transaction of British Mycological Society 57: 25-39.

14. Vidhyasekaran $P$, Muthamilan M (1995) Development of formulation of Pseudomonas fluorescens for control of chickpea wilt. PI Dis 79: 780-782.

15. Riker AJ, Riker RS (1936) Introduction to Research on Plant Diseases. John Swift, New York, NY, USA.

16. Bharathi R, Vivekananthan R, Harish S, Ramanathan A, Samiyappan R (2004) Rhizobacteria based bioformulations for the management of fruit rot infection in chillies. Crop Protect 23: 835-843.

17. Sarangi NP, Athukorala WG, Dilantha F, Khalid Y, Rashid Teresa de K (2010) The role of volatile and non volatile antibiotics produced by Pseudomonas chlorophis strain PA23 in its root colonization and control of Sclerotinia sclerotiorum. Biocon Sci Techn 20: 875-890.

18. Neidig N, Paul RJ, Scheu S, Jousset A (2011) Secondary metabolites of Pseudomonas fluorescens $\mathrm{CHA} 0$ drive complex non-trophic interactions with bacterivorous nematodes. Microb Ecol 61: 853-859.

19. Laha G, Singh RP, Venna JP (1992) Biocontrol of Rhizoctonia solani in cotton by fluorescent pseudomonads. Indian Phytopath 45: 412-415.

20. Manwar AV, Khandelwal SR, Chaudhari BL, Meyer JM, Chincholkar SB (2004) Siderophore production by a marine Pseudomonas aeruginosa and its antagonistic action against phytopathogenic fungi. Appl Biochem Biotechnol 118: 243-251.

21. Duffy B, Schouten A, Raaijmakers JM (2003) Pathogen self-defense: mechanisms to counteract microbial antagonism,. Annu Rev Phytopathol 41: 501-538.

22. Meena B, Marimuthu T, Vidhyasekaran P, Velazhahan R (2001) Biological control of root rot of ground nut with antagonistic Pseudomonas fluorescens strains. J PI Dis Prot 108: 369-381.

23. Sandeep Kumar M, Pandey P, Maheshwari DK (2009) Reduction in dose of chemical fertilizers and growth enhancement of sesame (Sesamum indicum L.) with application of rhizospheric competent Pseudomonas aeruginosa LES4. Euro J Soil Biol 45: 334-340.

24. Rachid D, Ahmed (2005) Effect of iron and growth inhibitors on siderophore production by Pseudomonas fluorescens. African J Biotech 4: 697-702.

25. Gupta CP, Dubey RC, Maheshwari DK (2002) Plant growth enhancement and suppression of Macrophomina phaseolina causing charcoal rot of peanut by fluorescent pseudomonads. Biol Fertil Soils 35: 399-405.

26. Thilagavathi R, Saravanakumar D, Ragupathi N, Samiyappan R (2007) A combination of biocontrol agents improves the management of dry root rot (Macrophomina phaseolina) in greengram. Phytopathol Mediterranea 46: 157-167. 